\title{
Journalists in Switzerland: Structures and attitudes revisited
}

\author{
Filip Dingerkus, ZHAW Zurich University of Applied Sciences, School of Applied Linguistics* \\ Annik Dubied, Université de Neuchâtel, annik.dubied@unine.ch \\ Guido Keel, ZHAW Zurich University of Applied Sciences, guido.keel@zhaw.ch \\ Vittoria Sacco, Université de Neuchâtel, vittoria.sacco@unine.ch \\ Vinzenz Wyss, ZHAW Zurich University of Applied Sciences, vinzenz.wyss@zhaw.ch \\ *Corresponding author: filip.dingerkus@zhaw.ch
}

\begin{abstract}
It is often stated that journalism and the media are going through some fundamental changes. In this article, we present a description of the journalists in Switzerland, based on a nation-wide survey conducted in 2015. This data gives a quantitative description of journalists in Switzerland. Furthermore, this article makes comparison between various groups of journalists, for example between the different language regions in Switzerland, in order to give a differentiated picture of who the journalists are, what their working situation looks like and how they perceive their own professional role in society.
\end{abstract}

\section{Keywords}

Journalism studies, Journalistic profession, Switzerland, survey

\section{Introduction}

One way of understanding journalism and change in the field is to survey the main actors of journalism, the journalists themselves. Based on this assumption, journalism surveys have been conducted regularly around the world for several decades (Weaver \& Wilnat, 2012, p. 1). In Switzerland, journalism surveys have taken place in 1980 (Saxer \& Schanne, 1981), 1998 (Marr, Wyss, Blum, \& Bonfadelli, 2001) and 2008 (Keel, 2011; Bonfadelli, Keel, Wyss, \& Marr, 2012). These surveys were based on similar studies conducted in Germany (Weischenberg, Löffelholz, \& Scholl, 1993, 1994) and the United States (Johnstone, Slawski, \& Bowman 1976; Weaver \& Wilhoit, 1986, 1996). All of them were looking for answers to the research questions put forward in the initial journalism surveys in the 1970s and used ever since by researchers involved in "the Global Journalist" efforts (Weaver \& Wilnat, 2012).

In 2007, a new international initiative was launched to understand how journalists were thinking and working around the world, called "Worlds of Journalism"
(Hanitzsch \& Seethaler, 2009). In its first round, this international survey covered Switzerland with a sample of 100 journalists from the German-speaking part of the country. For the second round, carried out in 2015, a nation-wide approach was chosen to fully represent the various language regions of the country and the different media types (Wyss \& Keel, 2010). This article is based on the data from this second round of the survey.

The main research questions are: Who are the journalists in Switzerland? What are the characteristics of their daily work? And what are their perceived roles and influences in their work?

The Swiss survey was carried out with three objectives in mind: (1) The survey should be in line with the "Worlds of Journalism" surveys elsewhere, in order to allow for comparisons across country boundaries (2) The survey should also be compatible to some extent with the Swiss surveys of 1998 and 2008, to allow for longitudinal comparisons (3) The survey should pick up new elements in the world of journalism to be able to describe the current state of the journalistic profes- 
sion in Switzerland. These three objectives were often contradictory, and thus it was decided that in case of conflict, the first objective was to be prioritized, while the third objective could be met by adding additional questions to the survey (for more details, see Methodology). However, this means that the new data gathered in 2014 and 2015 can only partly be compared to the data collected in the surveys of 1998 and 2008.

In the following sections, methodological aspects relevant to this survey will be presented, followed by the results of the survey describing the Swiss journalists. We will finish with a series of conclusions about the Swiss journalists in 2015. While this research cannot show to what extent journalism is changing in general, these findings allow for insights into journalism in Switzerland.

\section{Methodology and sample}

In 2015, a country-wide sample of roughly 1000 journalists was selected, based on the distribution of journalists according to the relative population of the three language regions and to the media type, as measured in the survey of 2008 (Keel, 2011).

In a first step, the editors-in-chief of 227 Swiss newsrooms were contacted in order to get their approval, as well as to raise the acceptance of the survey among the journalists. To include a wide variety of newsrooms, the number of journalists per newsroom was limited: for large news-

Table 1: Final sample compared to the sample of the 2008 survey (percentages)

\begin{tabular}{|c|c|c|c|c|c|c|}
\hline & & \multirow{2}{*}{$\begin{array}{l}\text { Survey from } 2008 \\
\qquad(N=2509)\end{array}$} & \multirow{2}{*}{$\begin{array}{l}\text { Survey from } 2015 \\
\qquad(N=909)\end{array}$} & \multicolumn{3}{|c|}{ Language Region } \\
\hline & & & & $\begin{array}{l}\text { German } \\
N=660 \\
(72.6 \%)\end{array}$ & $\begin{array}{l}\text { French } \\
N=176 \\
(19.4 \%)\end{array}$ & $\begin{array}{c}\text { Italian } \\
N=73 \\
(8 \%)\end{array}$ \\
\hline Gender & Female & 35.2 & 38.5 & 40.5 & 36.4 & 26.0 \\
\hline \multirow[t]{3}{*}{ Age } & Up to 35 & 26.4 & 32.0 & 33.8 & 28.2 & 23.6 \\
\hline & 35 to 44 & 31.5 & 28.7 & 28.3 & 29.4 & 30.9 \\
\hline & 45 and older & 42.1 & 39.3 & 37.9 & 42.4 & 45.5 \\
\hline Employment & Freelancer & 18.8 & 7.7 & 9.7 & 2.3 & 2.7 \\
\hline \multirow[t]{4}{*}{ Hierarchical role } & Managing role (chief editor) & 12.0 & 8.5 & 6.0 & 13.6 & 19.2 \\
\hline & $\begin{array}{l}\text { Partial managing role } \\
\text { (sectional chief etc.) }\end{array}$ & 28.3 & 18.5 & 20.2 & 14.2 & 15.1 \\
\hline & $\begin{array}{l}\text { No managing role } \\
\text { (editor, reporter, presenter etc.) }\end{array}$ & 48.4 & 67.7 & 68.9 & 65.9 & 61.6 \\
\hline & Trainee & 11.2 & 5.1 & 4.9 & 6.3 & 4.1 \\
\hline \multirow[t]{8}{*}{ Media type* } & Daily newspaper & & 26.1 & 23.3 & 33.5 & 32.9 \\
\hline & Weekly/sunday newspaper & & 12.0 & 11.7 & 14.2 & 9.6 \\
\hline & Magazine & & 9.2 & 10.3 & 6.3 & 6.8 \\
\hline & TV & & 10.0 & 9.2 & 9.7 & 17.8 \\
\hline & Radio & & 17.7 & 18.9 & 15.3 & 12.3 \\
\hline & News agency & & 3.2 & 2.1 & 6.3 & 5.5 \\
\hline & Online (indep.) & & 5.4 & 6.4 & 1.7 & 5.5 \\
\hline & Online (of offline media title) & & 4.4 & 4.1 & 6.3 & 2.7 \\
\hline \multirow[t]{3}{*}{ Mixed media types } & $\begin{array}{l}\text { Daily and weekly newspaper } \\
\text { (no main) }\end{array}$ & & 1.8 & 2.4 & & \\
\hline & $\begin{array}{l}\text { Daily newspaper and online } \\
\text { (no main) }\end{array}$ & & 2.8 & 2.9 & 2.8 & 1.4 \\
\hline & Other mix (no main) & & 7.5 & 8.6 & 4.0 & 5.5 \\
\hline
\end{tabular}

Note. *Due to differences in media type categories, a comparison with 2008 is not possible. 
rooms, five to eight journalists, for small newsrooms three to five journalists.

The survey design was within the framework provided by the Worlds of Journalism project. The questionnaire used a multi-layered analytical model (Weischenberg \& Scholl, 1998; Reese, 2001) and thus attempted to include organizational and societal context factors, since a journalist always works and functions as an actor within a society and usually as part of an organization. However, due to the questionnaire-based research design, the source of all the acquired information remained the individual journalist.

In order to make the questionnaire more meaningful for the Swiss context, certain questions and/or answer sets had to be adapted to local circumstances. Furthermore, questions which were considered to be of high relevance for the Swiss context were added to the questionnaire. This means that the wording of questions was kept in line with the surveys of 2008 and 1998 whenever possible.

The samples of the 2008 and 1998 surveys were partly drawn from membership lists of professional journalism associations, e.g. Impressum and Comedia, partly by contacting radio and TV stations. By contacting journalists only via newsroom, the sample of the 2015 survey was likely to differ in two ways. First, the approach via newsroom made sure that only active journalists, who were employed as such or at least worked actively as freelance journalists, were included in the survey. Second, by focusing on the variety of newsrooms, smaller media titles were better represented in the sample than in the previous surveys. One side effect of this focus on a wide representation of newsrooms and journalists was a much better representation of journalists from the Italian-speaking part of Switzerland, which represents 10 percent of the Swiss population.

While we were not able to get meaningful answers from all 1016 journalists that the survey sought to include, the sample of the 2015 survey can be considered the most diverse of all samples ever analyzed in a Swiss journalism survey in terms of representation of different language regions. At the same time, the selection of journalists via media titles and newsrooms as well as the premise including only journalists that gather at least $50 \%$ of their income from journalism lead to a lower representation of freelance journalists.

\section{Results}

In this section, the general results of the survey are presented and discussed. Furthermore, where an aspect of the survey allows for a meaningful breakdown into various sub-groups, a more detailed look at the data is presented.

\subsection{Five basic characteristics: Gender, age, education, origin, political stance}

In the survey of 2008, it was assumed that the total number of active Swiss journalists at that time was roughly 10500 . However, this number was mainly based on previous studies and media developments since then, plus on membership numbers of journalistic associations and unions. Thus, as was pointed out for 2008, this number was to be treated with great caution, since the definition of who is a journalist and the ways that they can be systematically counted have become less clear over the years. For 2015, it can be assumed that the number of journalists in the traditional sense has further decreased. This is based on the fact that while the number of radio and TV stations has remained more or less stable, there has been a reduction in independent newspaper titles and a reduction in staff in the newsrooms of the remaining newspapers (Lucht, 2010, p. 77). The few new titles and jobs in online media hardly compensated for those jobs lost in print.

For a general characterization of the Swiss journalists, this survey first looks at five variables which are unrelated to the journalistic profession: Gender, age, education, origin and political stance.

Gender: In 2015, 39\% of the journalists who took part in the survey were women. This is a further increase in the share of female journalists in Switzerland compared to previous studies. In 1980, 
Table 2: Highest educational degree of Swiss journalists ( $N=871)$

\begin{tabular}{l|cccc}
\hline & Total & $\begin{array}{c}\text { German-speaking } \\
\text { Switzerland }\end{array}$ & $\begin{array}{c}\text { French-speaking } \\
\text { Switzerland }\end{array}$ & $\begin{array}{c}\text { Italian-speaking } \\
\text { Switzerland }\end{array}$ \\
\hline Not completed high school & $9.1 \%$ & $10.4 \%$ & $6.9 \%$ & $2.7 \%$ \\
Completed high school & $10.9 \%$ & $12.3 \%$ & $5.2 \%$ & $12.3 \%$ \\
College/bachelor's degree or equivalent & $24.0 \%$ & $25.6 \%$ & $21.4 \%$ & $16.4 \%$ \\
Master's degree or equivalent & $42.3 \%$ & $37.0 \%$ & $56.1 \%$ & $54.8 \%$ \\
Doctorate & $3.3 \%$ & $3.8 \%$ & $1.7 \%$ & $2.7 \%$ \\
Some university studies, no degree & $10.4 \%$ & $10.9 \%$ & $8.7 \%$ & $11.0 \%$ \\
\hline
\end{tabular}

the percentage of female journalists in the two regions covered in that study was $17 \%$ (Saxer \& Schanne, 1981). By 1998, this number had risen to $32 \%$, and in 2008 to $35 \%$ (Keel, 2011). There is still a male bias in the newsrooms of newspapers $(42 \%$ of all male journalists vs. $32 \%$ of all female journalists), while magazines ( $13 \%$ of all women vs. $7 \%$ of all men) and radios $(21 \%$ of all women vs. $15 \%$ of all men) are preferred by women. This means that roughly $67 \%$ of all newspaper journalists are men, while $55 \%$ of all magazine journalists are women.

A closer look at the language regions shows that the share of women in the journalistic workforce is still largest in the German-speaking part of Switzerland. Here the differences between the language regions have increased significantly compared to the sample of 2008. The lowest percentage for female journalists can be found in the Italian-speaking part, where only $26 \%$ of all journalists were female.

Age: The average age of Swiss journalists has remained stable over the years. While it went from 41 to 43 between 1998 and 2008, it was back at 41.6 for 2015. The slightly lower average age is likely to be an effect of the different sampling method: While in the 2008 survey, journalists were partly selected based on membership lists of journalistic associations, where younger journalists often don't register and journalists keep their membership even after retirement, contacting journalists via newsroom made sure the survey includes only active journalists.

While there are no significant differences of average ages between language regions, there are some differences in the age structure between different media types. As was noted in previous studies, the journalists at private broadcasting stations tend to be much younger than journalists working for other media. This is particularly true for private radio, where the average age is about 32. Journalists working for online media also tend to be younger (37.5 for websites of offline media, 39 for online-only media), but the average age for online media is clearly higher than for those working for a private radio station. The highest average age, on the other hand, can be found among journalists working for the public service TV station (46.5). While only about $12 \%$ of all journalists working for the public broadcasting radio station are younger than 30 years old, this percentage increases to $51 \%$ when looking at private broadcasters.

Education: The third sociodemographic variable deals with education. A general overview shows that more than two thirds of the surveyed journalists in Switzerland have an academic degree. Furthermore, almost half of the academics $(47 \%)$ said that they have received their degree in journalism, communications or a related field.

A more detailed look at the language regions shows some striking differences between the German and the French-/ Italian-speaking part of Switzerland: The share of journalists with master's degrees in the French and Italian region is almost $20 \%$ higher as in the German-speaking part. One explanation could be that only in the French-speaking part of the country there is an academic master's program in journalism. 
Table 3: Highest education in longitudinal comparison

\begin{tabular}{l|ccc}
\hline & $\begin{array}{c}1998 \\
(\mathrm{~N}=1997)\end{array}$ & $\begin{array}{c}2008 \\
(\mathrm{~N}=2460)\end{array}$ & $\begin{array}{c}2015 \\
(\mathrm{~N}=871)\end{array}$ \\
\hline High school or professional degree at the most & $28 \%$ & $27 \%$ & $20 \%$ \\
Attended university, but no degree & $18 \%$ & $16 \%$ & $10 \%$ \\
University degree & $54 \%$ & $57 \%$ & $70 \%$ \\
\hline
\end{tabular}

A strict comparison with earlier surveys is difficult, because the response items for the education in earlier surveys were more detailed. However, in broad terms, a general comparison (academics vs. non academics) is still possible, and it reveals that the journalistic profession has become even more academic compared to 2008 . This is in line with a finding that has been made before: in an increasingly complex profession, journalists are more and more likely to be educated at a university (Keel, 2011, p. $168 \mathrm{ff}$.).

Origin: To further describe the nature of the profession, the survey looked at the country of origin of Swiss journalists. Already in 2008, it could be shown that the immigrant part of Swiss society, which makes up for $24 \%$ in the Swiss population at the end of 2014 (Bundesamt für Statistik, 2016), is starkly under-represented among journalists. While this finding could be confirmed for 2015, the numbers indicate that the extent of the misrepresentation has diminished, compared to 2008.

Table 4: Percentage of foreigners among Swiss journalists, by language region

\begin{tabular}{l|cccc}
\hline & Total & $\begin{array}{c}\text { German- } \\
\text { speaking } \\
\text { Switzerland }\end{array}$ & $\begin{array}{c}\text { French- } \\
\text { speaking } \\
\text { Switzerland }\end{array}$ & $\begin{array}{c}\text { Italian- } \\
\text { speaking } \\
\text { Switzerland }\end{array}$ \\
\hline 2015 & 17 & 13 & 24 & 28 \\
2008 & 9 & 7 & 12 & 21 \\
$(\mathrm{~N}=2460)$ & & & & \\
\hline
\end{tabular}

The question about the journalists' mother tongue reveals that a large share of foreign journalists in Switzerland comes from nearby: While $13 \%$ of all journalists in the German-speaking part are not Swiss, still only $4 \%$ do not have German as their mother tongue. This number is even higher for the French-speaking part (only 3\% with a mother tongue other than French), and for the Italian-speaking part (only $1 \%$, or three journalists in the survey sample with a mother tongue other than Italian).

Political Stance: Finally, a fifth sociodemographic variable to describe journalists deals with the political orientation. For the first time in Switzerland, this survey shows for all of Switzerland and all media types where journalists see themselves on the political spectrum.

The overall view shows that Swiss journalists, on average, are slightly to the left of the political center. On a scale from 0 (left) to 10 (right), with 5 being the center, Swiss journalists on average see themselves at 4.02 .

Figure 1: Political stance of journalists in Switzerland ( $N=797)$

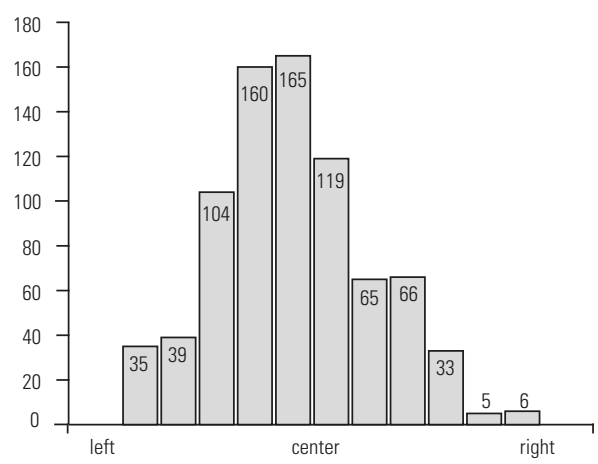

This picture applies for all language regions. As for significant differences between groups, such a difference can be found between women, who tend to be more left (3.6), and men (4.2). No statistically significant difference can be found 
between journalists working for private media (4.0), which include both private broadcasters and print media, and journalists working for the public broadcasting company (3.8). This result both confirms a cliché and tempers it: journalists consider themselves to be slightly progressive, but not as much as it is commonly assumed.

\subsection{Working situation}

An economic crisis in a sector of the economy is often associated with deteriorating working conditions, which manifest themselves in a larger share of temporary and part-time jobs. With the media facing economic difficulties, it could be expected that more journalists work in temporary positions and part-time, and that the need to take on other paid jobs would be higher.

The percentage of journalists working in temporary positions is 6\% in 2015. Temporary employment among female journalists was considerably higher, at $8 \%$, while it was at only $4 \%$ for men.

Furthermore, in 2015, 57\% of all journalists worked full-time, which is less compared to other countries in the survey as the country reports on the worlds of journalism website show. Germany for example has $74.5 \%$ and Austria $77 \%$ full-time employment (Hanitzsch, Steindl, \& Lauerer, 2016; Lohmann \& Seethaler, 2016).

Figure 2: Percentages of salary classes among Swiss journalists ( $N$ for $2015=859, N$ for $2008=1788$, $\mathrm{N}$ for $1998=1988$ )

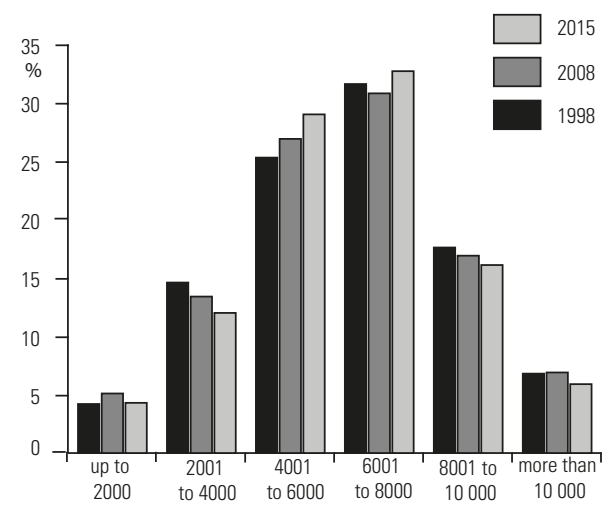

A look at gender differences again shows that the share of women working full-time is much lower, at $43 \%$, than that of men (66\%). It is thus no surprise that more women stated that they had other paid jobs (24\%) compared to men (20\%).

An important aspect of the working situation in any profession is the level of the salary. In a deteriorating working environment, one would expect diminishing wages over time. However, the general comparison shows that wages have barely changed over the last twenty years. While real wages diminished from 1998 to 2008 due to inflation, the wage level in journalism over the last seven years can be described as stable, both in nominal and in real terms.

There are, however, the same differences between certain groups, as there have been in the past. First, there is a clear difference in salary between men and women: Women remain over-represented in the lower salary classes, while men are over-represented in the higher ones amongst journalists who earn 6000 Swiss francs and more. This remains true even if only regular editors without leadership roles are compared.

Second, there is a difference between the language regions when it comes to the distribution of salary classes: Journalists in

Figure 3: Share of journalists in salary classes according to gender (only senior editors, producers, reporters and news writers; $\mathrm{N}=551$ )

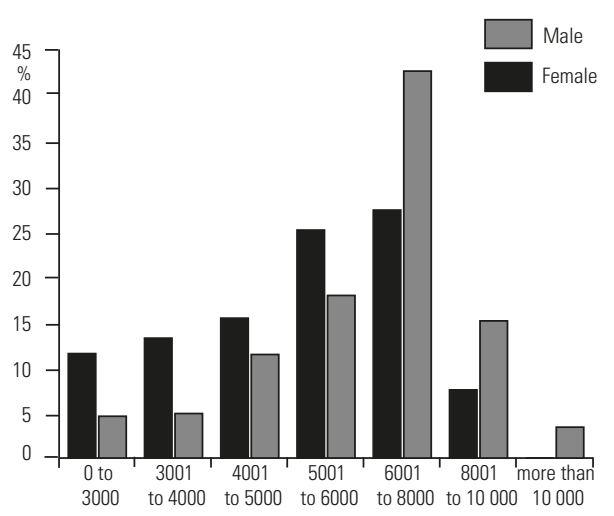


Figure 4: $\quad$ Salary according to media type $(N=756)$

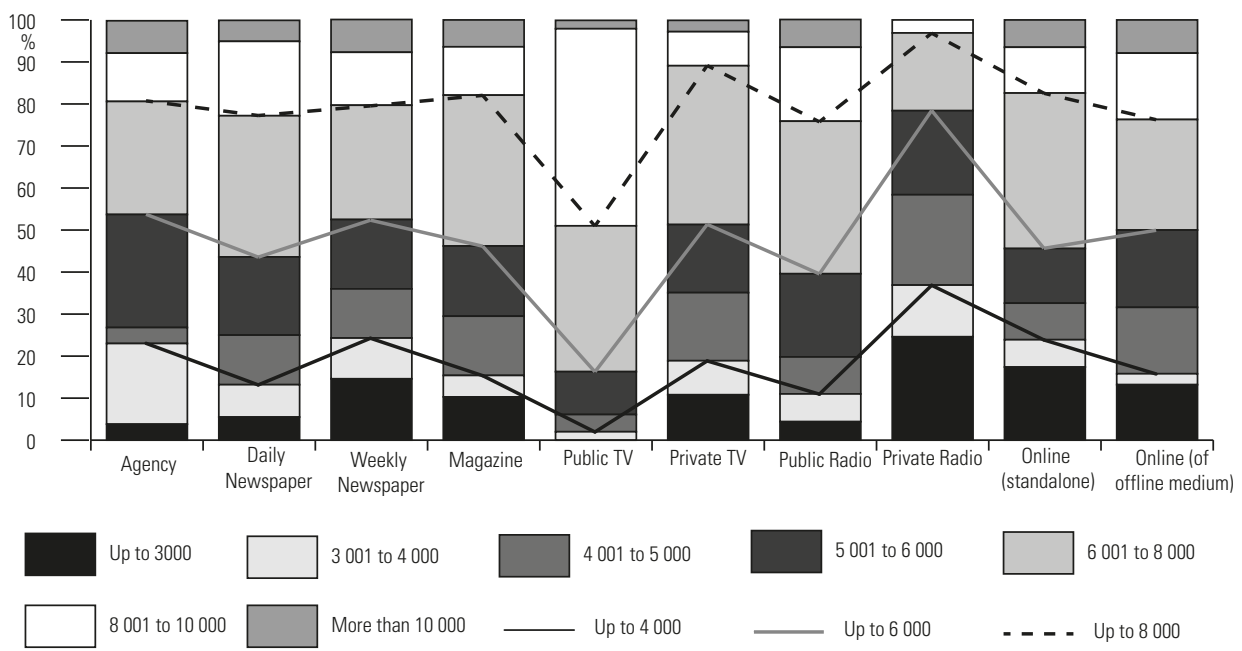

the German-speaking part are over-represented in the higher salary classes, compared to the colleagues in the French- and Italian-speaking regions.

The most striking difference, however, can be found between media types. As the following diagram with stacked columns shows, media types such as private radio or private TV have a much larger share of journalists who have a salary up to 6000 Swiss francs than journalists from other media types. At the same time, journalists working for the public TV station have hardly any journalists in the lower salary classes; half the journalists there are in the salary classes of 8000 Swiss francs and above.

\subsection{Editorial organization}

The logical way to organize a newsroom has typically been according to topics, or beats. This allows a journalist within a team to specialize in his or her field. However, this organizational logic has been under pressure recently, as newsroom capacities are reduced and journalists are more often forced to cover all kinds of topics. On the other hand, emerging convergent newsroom structures have shifted the focus of the organization away from outlet-specific structures and towards a focus on topics or issues, which would support a strengthening of issue-related structures.

The 2015 data show that slightly less than half the journalists work on a specific beat $(48 \%)$, while a small majority $(52 \%)$ work on various topics and subjects. There is no significant difference between language regions or gender. However, there are significant differences between different media types:

Table 5 clearly shows that an organization along specific topics, i.e. in beats, is often found in newsrooms of the public

Table 5: $\quad$ Percentage of journalists working for a specific beat, according to media type $(\mathrm{N}=901)$

\begin{tabular}{l|c}
\hline Work on a specific beat & Percentage \\
\hline Total & $48 \%$ \\
News Agency & $86 \%$ \\
Public service radio (only) & $58 \%$ \\
Daily newspaper & $52 \%$ \\
Print magazine & $52 \%$ \\
Public service TV (only) & $51 \%$ \\
Weekly newspaper & $47 \%$ \\
Online (of offline media) & $43 \%$ \\
Online (Stand-alone) & $35 \%$ \\
Private TV & $24 \%$ \\
Private radio & $12 \%$ \\
\hline
\end{tabular}


broadcasting company. News agencies are the only media type with an even higher percentage of journalists that work on a specific beat. Print media and online media follow in third and fourth position. Private radio and TV are at the other end of the spectrum: less than a quarter of all journalists working for private TV stations, and only $12 \%$ of private radio journalists, are assigned to a specific beat.

Another differentiation can be made in terms of gender. As previous studies have shown, there is a gender bias when it comes to the question on which topics female and male journalists work (Keel, 2011, p. 149). Men are still over-represented when it comes to the "hard news" - politics and economics -, while women are more likely to work in culture, society/ lifestyle, and local news. The most uneven distribution, however, is still found in sports.

Table 6: Distribution of journalists between beats, according to gender (for those journalists working in newsrooms with dedicated beats; in percent; $\mathrm{N}=430$ )

\begin{tabular}{l|cc}
\hline & Female & Male \\
\hline Politics & $26 \%$ & $36 \%$ \\
International news & $2 \%$ & $3 \%$ \\
Domestic news/politics & $13 \%$ & $18 \%$ \\
News, information & $11 \%$ & $16 \%$ \\
Local news & $11 \%$ & $10 \%$ \\
Economics/finance & $10 \%$ & $13 \%$ \\
Culture & $14 \%$ & $11 \%$ \\
Sports & $1 \%$ & $15 \%$ \\
Society/lifestyle/other & $37 \%$ & $14 \%$ \\
\hline
\end{tabular}

\subsection{Role perception}

In journalism studies, it is commonly assumed that the understanding of one's role in society has an impact on the work of journalists (Weischenberg, 1994, p. 241). Therefore, it is relevant to look at how journalists see themselves. The question of whether or not it is possible for a journalist to fulfill this role remains open. However, the findings give an indication as to how a journalist ideally sees his or her role and the role of journalism in society.

As Weaver pointed out in 2008, the understanding of one's role as journalist is characterized by stability, rather than change. The current data for Switzerland support this finding. The overall ranking of importance is in line with earlier surveys, and it shows little variation across language boundaries in Switzerland.

In the 2008 survey, three types of journalists emerged from a factor analysis of preferences for certain roles: first, the "objective reporter"; second, the "activist critic and commentator"; and third, the "audience-oriented journalist."

In the 2015 survey, a different and more detailed list of role understanding was used. This leads to the emergence of different journalistic role types with the help of a factor analysis. The analysis verified that the typical roles still exist, but not all variables indicated a clear tendency towards one factor. These questions didn't show an affiliation to one of the five defined types and was therefore labeled "no clear type." While the objective reporter and the audience-oriented journalist could be identified again, the activist role from the earlier study (2008) splits itself into two different types according to the definition of the factor dimensions (which emerge from the common elements of the matching questions): The political journalist, who criticizes those in power and thus enables people to participate in democracy, and the social activist, whose focus lies more on the education of the audience to promote social change, emphasizing cultural diversity. Another role type to be found was the audience-oriented journalist, who sees his role mainly in the provision of entertaining content, which attempts to attract the largest possible audience. Finally, based on new role understanding used in the 2015 survey, a fifth type emerged, which can be labelled "state-friendly," and which characterizes itself as being close to the state, supporting government policies.

A comparison of these types with the importance given to each role shows a clear pattern: roles associated with the 
Table 7: Importance of different journalistic roles according to journalist type (scale: $5=$ extremely important to $1=$ not important; $\mathrm{N}=908$ )

\begin{tabular}{lll}
\hline Item & Value & Role Type \\
\hline Report things as they are & 4.53 & Objective reporter \\
Be a detached observer & 4.26 & Objective reporter \\
Provide analysis of current affairs & 4.21 & No clear type \\
Provide information people need to make political decisions & 3.79 & Political activist \\
Let people express their views & 3.54 & No clear type \\
Tell stories about the world & 3.48 & No clear type \\
Promote tolerance and cultural diversity & 3.45 & Social activist \\
Provide the kind of news that attracts the largest audience & 3.34 & Audience-oriented \\
Monitor and scrutinize political leaders & 3.25 & Political activist \\
Motivate people to participate in political activity & 3.24 & Social activist \\
Provide advice, orientation and direction for daily life & 3.20 & No clear type \\
Provide entertainment and relaxation & 3.13 & Audience-oriented \\
Educate the audience & 3.11 & No clear type \\
Monitor and scrutinize business & 3.07 & Political activist \\
Advocate for social change & 2.60 & Social activist \\
Set the political agenda & 2.59 & Political activist \\
Be an adversary of the government & 2.56 & Political activist \\
Influence public opinion & 2.52 & No clear type \\
Support national development & 2.26 & No clear type \\
Support government policy & 1.50 & State-friendly \\
Convey a positive image of political leadership & 1.29 & State-friendly \\
\hline
\end{tabular}

objective reporter are the most important ones in the eyes of the journalists, while those related to the state-friendly-journalist type are seen as least important.

When comparing language regions, different journalistic cultures can be detected: German-speaking journalists are more audience-oriented than their colleagues in French- and Italian-speaking Switzerland. On the other hand, journalists in the French- and Italian-speaking parts of Switzerland see themselves as more political than journalists in the German-speaking part.

\subsection{Perception of influence}

Ideally, journalism is independent. It should be able to function without either economic or interests influencing their work. At the same time, journalism does not take place in a vacuum. It is part of society and serves various stakeholder groups' needs and expectations. In order to understand what needs, expectations and interests influence journalists and their work, journalists were asked the question: What influences you and your work as journalist. More specifically, they were confronted with 27 possible sources of influence.

A factor analysis shows that there are five categories of factors which influence journalistic work, according to the answers in the survey: 1) factors related to the media system and the power relations between the media and other institutions of society, such as politicians, economic leaders or other pressure groups; 2) internal factors, such as Editorial supervisors, peers, or managers of one's media organization; 3) external audience-related factors, including feedback from friends and from journalists from other media; 4) economic factors, such as advertising or profit considerations, and 5) resource-related factors, such as time or other resources to gather news, or information access. Some of the variables did not indicate a specific factor and were defined as "not categorized."

As could be seen for role understanding, there is also a clear order of relevance 
Table 8: Average assessment of relevance of sources of influence ( $5=$ very influential, $1=$ least influential; $\mathrm{N}=896$ )

\begin{tabular}{|c|c|c|}
\hline Source of Influence & Relevance & Category \\
\hline Journalism ethics & 3.68 & Could not be categorized \\
\hline Time limits & 3.55 & Resources \\
\hline Personal values and beliefs & 3.51 & Could not be categorized \\
\hline Information access & 3.49 & Resources \\
\hline Availability of news-gathering resources & 3.47 & Resources \\
\hline Editorial policy & 3.02 & Could not be categorized \\
\hline Editorial supervisors and higher editors & 2.93 & Internal \\
\hline Relationships with news sources & 2.87 & Could not be categorized \\
\hline Peers on the staff & 2.82 & Internal \\
\hline Media laws and regulation & 2.73 & Could not be categorized \\
\hline Feedback from the audience & 2.54 & External audience \\
\hline Competing news organizations & 2.50 & External audience \\
\hline Audience research and data & 2.45 & Could not be categorized \\
\hline Friends, acquaintances and family & 2.30 & External audience \\
\hline Public relations & 2.24 & could not be categorized \\
\hline Managers of your news organization & 2.22 & Internal \\
\hline Colleagues in other media & 2.17 & External audience \\
\hline Profit expectations & 2.12 & Economics \\
\hline Pressure groups & 2.00 & Power \\
\hline Advertising considerations & 1.97 & Economics \\
\hline Business people & 1.89 & Power \\
\hline Politicians & 1.87 & Power \\
\hline Owners of your news organization & 1.86 & Internal \\
\hline Government officials & 1.75 & Power \\
\hline The military, police and state security & 1.69 & Could not be categorized \\
\hline Censorship & 1.50 & Could not be categorized \\
\hline Religious considerations & 1.39 & Could not be categorized \\
\hline
\end{tabular}

attributed to the five different sources of influence. The internal sources of influence are clearly seen as most important, as they cluster on top of the table, while those related to political power or other pressure groups are seen as least influential. This confirms the thesis that while journalism in Western democracies is under great pressure from various sides and actors, political aspects and actors usually exert the smallest influence on journalism (Czepek, 2010).

\subsection{Job satisfaction}

The last journalists' survey in Switzerland took place just about when the crisis in the media, namely the print media, had started to be felt. Despite the starting talk of crisis, back then, $73 \%$ of all journalists still said that they would recommend journalism as a profession, down from $77 \%$ in 1998. This number has remained steady at $74 \%$ in 2015 . Interestingly, this view is shared from the top of the editorial hierarchy to the bottom, from editors-in-chief $(80 \%)$ to the interns $(67 \%)$, the only exception being "news writers," most of whom wouldn't recommend the journalistic profession (only $42 \%$ would recommend it). There are differences in attitude between journalists in the three language regions (around $72 \%$ who recommend the profession in the German-speaking part, $78 \%$ in the French-speaking part and $84 \%$ in the Italian-speaking region). Also media types seem to have an influence on the perception of the desirability of the profession journalists working for print media rec- 
ommend the journalistic profession less $(68 \%)$ than those working for radio (83\%) or TV $(84 \%)$, no matter whether the company they work for is private or public. In addition, older age groups recommend the profession less often (69\%).

\section{Discussion}

Although the representation of women in journalism gets stronger with the years, still $61 \%$ of our sample are men. The smaller share of women is especially true for higher positions, which again can partly be explained by the lack of highly experienced women. The older journalists are, the larger the share of men. The overall average age is 41.6 years and there are only few significant differences according to for example gender and region. One of the main differences according to age appears in media types. Younger journalists tend to work for private radios and online while older ones for the public service. Typically more stable working conditions in the public sector and the economy driven lower pressure to higher cheap labor in the private sector are likely explanations. While the percentage of highly educated journalists is steadily growing, the amount of foreign journalists is still under-represented in our sample, though higher than in earlier surveys. Lack of incentives and the language barrier might be possible explanations. Furthermore, the often-stated assumption that journalists are often politically left-leaning is indeed visible, but not extreme. On average, journalists see themselves slightly left to the political center.

The working situation is still tense as salaries haven't changed much between 1998, 2008 and now 2015 (Keel, 2011). The difficult financial situation applies especially to journalists in the private sector, as they are still earning significantly less than their colleagues working for public service media.

As far as the editorial organization is concerned, some elements seem to have changed in recent years, especially according to media type and beat. A large share of journalists in our sample work for different media types and in different beats. $12.1 \%$ of the interviewed journalists cannot define their main media type because they either work in a convergent newsroom or produce to equal extent for different outlets.

Unchanged figures can be observed for the role perceptions as well as the influences. Our Swiss journalists strongly identify themselves with the objective reporter and feel the pinch on their daily work from resource-related influences like time or information access.

Nevertheless they are mostly satisfied with their job and are intrinsically motivated carrying on with their profession. And despite harshening circumstances and increasing pressure, $74 \%$ would still recommend journalism.

\section{Conclusions}

Journalism surveys often end with a description of the typical journalist. However, there is no typical journalist in Switzerland. To say that the typical Swiss journalist was male would ignore the fact that more and more journalists are female. To say that the typical journalist works for a daily newspaper would ignore the fact that more and more journalists are not working for one media title anymore, but supply on- and offline channels with their work.

Instead, it can be said that while the data from this journalism survey reflects some changes that the journalistic profession is going through, it draws a picture that still resembles that of 2008 . Two reasons are likely to contribute to this: 1) In the Worlds of Journalism project, of which this is part, it was agreed that the objects of analysis were the journalists working for journalistic print products, for radio, TV and journalistic news websites. These journalists can be seen as the core of the professional field of journalism. It is one finding of this survey that in this core, there is a lot of stability - maybe not quantitatively, when it comes to the number of journalists, but qualitatively: little change 
in terms of sociodemographic. However, this leaves out the fringes of the professional field - the bloggers, the journalistic satirists, the political talk show hosts, the special-interest websites, etc. To what extent journalism is changing in these fields cannot be measured with this data. Considering these fringes could show a different understanding of the journalistic profession. 2) The findings in journalist surveys are always based on what journalists tell the researchers. These answers may sometimes be more of a reflection of what should be or what one would like it to be, and not so much what actually is. What has been said in earlier surveys still applies: Journalism surveys of this type probably measure a shared understanding of professional norms more than the actual situation of journalists and journalism (Keel, 2011, p. $267 \mathrm{ff}$.).

However the data still provides a comprehensive picture of professional field of journalism in Switzerland in 2015. To fully understand the various actors involved in journalism and to holistically depict the field it might be helpful in future surveys to especially keep methodological approaches and the questionnaire unaltered but also to broaden the view and look beyond what is generally considered as "the Swiss journalist."

\section{Acknowledgements}

This study has been funded by the Swiss National Fund (SNF) and the Institute of Applied Media Studies (IAM) at the Zurich University of Applied Studies (ZHAW).

\section{References}

Bonfadelli, H., Keel, G., Wyss, V., \& Marr, M. (2012). Journalists in Switzerland: Structures and attitudes. Studies in Communications Sciences, 11(2), 7-26.

Bundesamt für Statistik (Federal Statistical Office) (2016). Bevölkerung: Sprachen Daten, Indikatoren. Retrieved from http:// www.bfs.admin.ch/bfs/portal/de/index/ themen/01/05/blank/key/sprachen.html
Hanitzsch, T. \& Seethaler, J. (2009). Journalismuswelten: Ein Vergleich von Journalismuskulturen in 17 Ländern. Medien \& Kommunikationswissenschaft, 57(4), 464-483.

Hanitzsch, T., Steindl, N., \& Lauerer, C. (2016). Country report: Journalists in Germany. Worlds of Journalism Study.

Johnstone, J.W.C., Slawski, E. J., \& Bowman, W.W. (1976). The news people: A sociological portrait of American journalists and their work. Urbana: University of Illinois Press.

Keel, G. (2011). Journalisten in der Schweiz. Eine Berufsfeldstudie im Zeitverlauf. Konstanz: UVK.

Lohmann, M.-I. \& Seethaler J. (2016). Country report: Journalists in Austria. Worlds of Journalism Study.

Lucht, J. (2010). Presse - Publizistische Versorgung. In fög - Forschungsbereich Öffentlichkeit und Gesellschaft der Universität Zürich (Eds.), Jahrbuch 2010 Qualität der Medien. Schweiz-Suisse-Svizzera (pp. 77-83). Basel: Schwabe.

Marr, M., Wyss, V., Blum, R., \& Bonfadelli, H. (2001). Journalisten in der Schweiz. Konstanz: UVK Medien.

Reese, S. D. (2001). Understanding the Global Journalist: a hierarchy-of-influences approach. Journalism Studies, 2(2), 173-187.

Saxer, U. \& Schanne, M. (1981). Journalismus als Beruf. Eine Untersuchung der Arbeitssituation von Journalisten in den Kantonen Zürich und Waadt. Bern: Eidg. Justiz- und Polizeidepartement.

Weaver, D. H. (2008). Stability and change contradictions in U.S. journalism. In B. Pörksen, W. Loosen, \& A. Scholl (Eds.), Paradoxien des Journalismus. TheorieEmpirie-Praxis (pp. 183-1921). Wiesbaden: VS Verlag für Sozialwissenschaften.

Weaver, D. H. \& Wilnat, L. (2012). The global journalist in the $21^{\text {st }}$ century. New York and London: Routledge.

Weaver, D. H. \&Wilthoit, G. C. (1996). The American Journalist in the 1990s. US News People at the End of an Era. Mahwah: Lawrence Erlbaum.

Weaver, D. H. \& Wilthoit, G. C. (1986). The American journalist. Bloomington: University of Indiana Press. 
Weischenberg, S. (1994). Konzepte und Ergebnisse der Kommunikatorforschung. In: O. Jarren (Ed.) Medien und Jourrnalismus 1. Eine Einführung (pp. 227-239). Opladen, Wiesbaden: Westdeutscher Verlag.

Weischenberg, S., Löffelholz, M., \& Scholl, A. (1994). Journalismus in Deutschland II: Merkmale und Einstellungen von Journalisten. Media Perspektiven, 4, 154-167.

Weischenberg, S., Löffelholz, M., \& Scholl, A. (1993). Journalismus in Deutschland. Media Perspektiven, 1, 21-33.

Weischenberg, S. \& Scholl, A. (1998). Journalismus in der Gesellschaft. Theorie, Methodologie und Empirie. Opladen/Wiesbaden: Westdeutscher Verlag GmbH.

Wyss, V. \& Keel, G. (2010). Schweizer Journalismuskulturen im sprachregionalen Vergleich: Eine quantitative Längsschnittuntersuchung zu Strukturmerkmalen und Einstellungen. In A. Hepp, M. Höhn \& J. Wimmer (Eds.), Medienkultur im Wandel (pp. 245-260). Konstanz: UVK Verlagsgesellschaft. 